\title{
Clinical experience and long-term outcome after subscleral insertion of a cyclosporine A drug delivery device in horses with immune-mediated keratitis
}

\author{
József Tóth, Stefanie Huthmann und Josef Hollerrieder \\ Tierklinik Hochmoor, Gescher-Hochmoor
}

\begin{abstract}
Summary
The purpose of this study was to determine the efficacy and duration of effect of a subscleral cyclosporine A implant in horses with immune-mediated keratitis (IMMK). The study at hand describes the cases of fifteen horses with mature IMMK that were presented to the Tierklinik Hochmoor for further treatment. In theses horses, a cyclosporine A drug delivery device was placed subsclerally adjacent to the suprachoroidal space under general anesthesia. Follow-up was evaluated for up to 53 months duration after implant placement. Objective assessment showed an improvement in $66.7 \%$ of patients. Four of the patients suffered a recurrence of symptoms. This study yields promising results for the long-term treatment of IMMK in horses. Sport horses and patients suffering from frequently recurring episodes of IMMK could benefit greatly from this alternative treatment method.
\end{abstract}

Keywords: immune-mediated keratitis / equine / cyclosporine / implant / drug delivery device / surgery

Klinische Erfahrungen und Langzeitergebnisse nach subskleraler Implantation eines Cyclosporin A-Trägersystems bei Pferden mit immunvermittelter Keratitis

Der Terminus immunvermittelte Keratitis umfasst eine Gruppe von Hornhauterkrankungen, die durch eine Fehlregulierung des kornealen Immunsystems verursacht werden. In der Regel gehen diese Erkrankungen nicht mit einer Uveitis einher und sind auch nicht schmerzhaft. Sie zeichnen sich durch ein Hornhautödem, eine Gefäßeinsprossung und eine unterschiedlich starke Ausprägung zellulärer Infiltrate aus. In der vorliegenden Studie wurde an der Tierklinik Hochmoor bei 15 Pferden mit immunvermittelter Keratitis ein Cyclosporin A-Implantat in Allgemeinanästhesie eingesetzt. Das Trägersystem wurde bereits in verschiedenen human- und tiermedizinischen Studien verwendet und besteht aus einer Silikonmatrix, in die ein 10\% Cyclosporin A-Pulver Pellet eingelassen ist. Das Implantat wurde subskleral platziert, so dass es direkt an den suprachoroidalen Raum angrenzte. Der weitere klinische Verlauf der so versorgten Patienten konnte zum Teil über 53 Monate verfolgt werden. Eine objektive Auswertung ergab eine Verbesserung des klinischen Bildes in 66,7\% der Fälle; vier der Pferde erlitten ein Rezidiv der immunvermittelten Keratitis. Dieser innovative Behandlungsansatz lässt auf verbesserte Therapiemöglichkeiten für die Langzeitbehandlung der immunvermittelten Keratitis hoffen. Gerade Sportpferde und Patienten mit häufig auftretenden Rezidiven könnten von dieser Behandlungsmethode profitieren.

Stichwörter: immunvermittelte Keratitis / Pferd / Cyclosporin / Implantat / Trägersystem / Operation

\section{Introduction}

The term immune-mediated keratitis (IMMK) refers to a group of corneal diseases that are proven or suspected to be caused by a dysfunction of the corneal immune response. The exact etiology of IMMK is still unknown, but they are typically nonulcerative and show varying degrees of corneal edema, vascularization, and cellular infiltrate. Signs of uveitis, intraocular inflammation or pronounced ocular pain can usually not be detected. To date, the nomenclature of the many clinically and histopathologically different IMMK is still inconsistent, but generally three types are distinguished:

Superficial keratitis - This type of IMMK presents itself with a superficial cellular stromal infiltrate of a white or slightly yellow color and a diffuse vascularization with or without pigmentation of the cornea (Fig. 1). Midstromal keratitis: This type is more diffuse and has a midstromal, denser cellular infiltrate surrounded by a slight corneal edema and vascularization (Fig. 2).

Endothelial keratitis - This type comes along with an endothelial infiltrate and a diffuse superficial or midstromal corneal edema as well as mild vascularization (Brooks et al.
1990, Kellner 1990, Matthews 2000, Gilger et al. 2005, Matthews and Gilger 2009, Matthews and Gilger 2010, Toth et al. 2010, Clode et al. 2011).

The treatment of equine IMMK is a major challenge to the ophthalmologist. In many cases, the topical treatment with corticosteroids yields good results. However, corticosteroids have several disadvantages, such as their distinct adverse side effects and the fact that they are registered in the FEI Prohibited Substances List. Immunosuppressant agents derived from bacteria or fungi represent a significant therapeutic alternative. They are less toxic, have fewer adverse side effects, and, last but not least, have been available in preparations for topical use for some time now. The most important agents in this group are cyclosporine A, FK 506, pimecrolimus, and rapamycin (Sigal and Dumont 1992, Reinhard et al. 1996, Ruhlmann and Nordheim 1997, Mabon et al. 1999, Soter et al. 2001, Kopf et al. 2007, Douglas et al. 2008). Until recently, those agents have primarily been employed in human transplant medicine (Maske et al. 1994, Reinhard et al. 1996, Cao et al. 1999, Zhang et al. 2000). Their pharmacological principle is based on the adhesion to intracellular proteins, the so-cal- 
led immunophilines. Cyclosporine A forms a complex with those proteins which leads to the inhibition of calcineurin, suppressing the transcription of proinflammatory cytokines and thus downregulating immunocyte activity. The exact mechanism is well understood today and shall not be the subject of this article. In addition to this main mode of action, cyclosporine $A$ also has other immunological effects. It reduces the expression of IL-3, IL-4, and GM-GSF in T-lymphocytes and inhibits the proliferation of B-lymphocytes as a secondary reaction to the reduced cytokine production of the T-lymphocytes (Borel et al. 1976, Kay 1989, Kawai et al. 2005, Zhang et al. 2008, Abadja et al. 2009, Liv et al. 2009).

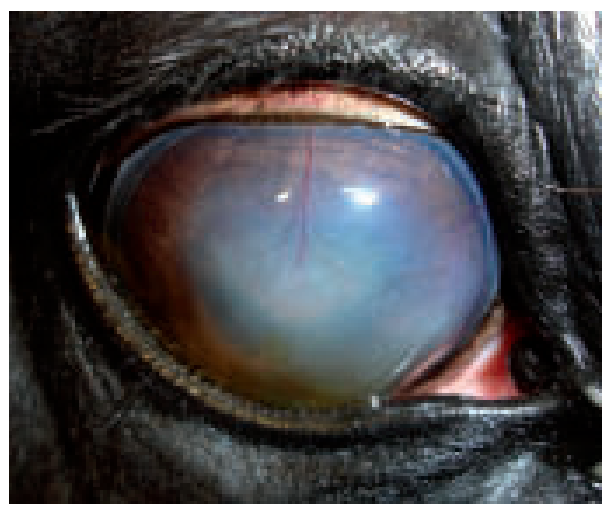

Fig. 1 Right eye of a 9 year-old warmblood mare. Superficial keratitis with marked vascularization and corneal edema.

Rechtes Auge einer 9jährigen Warmblutstute. Man erkennt eine superfizielle Keratitis mit deutlicher Gefäßeinsprossung und einem Hornhautödem

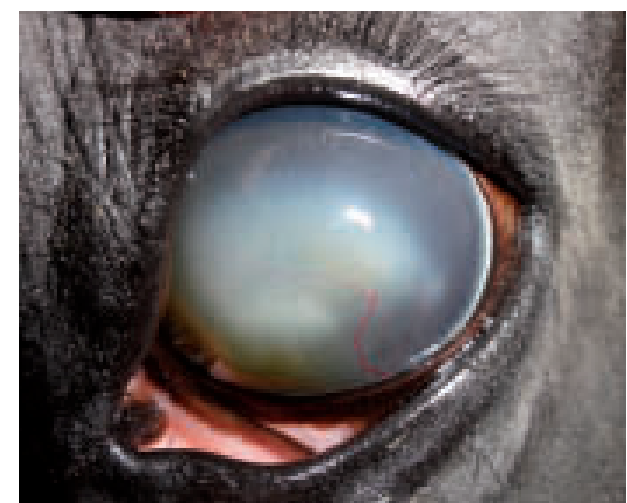

Fig. 2 Left eye of a 6 year-old warmblood gelding. Midstromal keratitis with diffuse cellular infiltrate, corneal edema and vascularization.

Linkes Auge eines bjährigen Warmblutwallachs. Man erkennt eine midstromale Keratitis mit einem diffusen zellulären Infiltrat, einem Hornhautödem und einer Gefäßeinsprossung.

Cyclosporine $A$ is used in human and veterinary ophthalmology in the form of ointments or drops in chronic inflammatory diseases of the cornea and conjunctiva that are resistant to other forms of therapy (Minguez et al. 1992, Freisen 1993, Holland et al. 1993, Gratzek et al. 1995, Gao et al. 1998, Heiligenhaus and Steuhl 1999, Hingorani et al. 1999). Topically applied, cyclosporine A is chiefly absorbed by the cornea where it accumulates in the different layers according to the cellular density of the respective layer. Following uptake, $60 \%$ of the drug can be found in the epithelium, $30 \%$ in the stroma, and $11 \%$ in the endothelium. Also, cyclosporine $A$ is metabolized in the anterior aspect of the eye; its metabolites can be detected there. Due to the low rate of penetration of topically applied cyclosporine A drops the concentration of the drug in the anterior chamber of the eye is low. The topical use is still the preferred method of application, even though it only yields a low concentration of cyclosporine A in the eye (BenEzra et al. 1986, BenEzra and Maftzir 1990, Bleik and Tabbara 1991, Holland et al. 1993, Althaus et al. 1996, Dua et al. 1996, Secchi et al. 1997, Tran 1997, Williams 1997, Acheampong et al. 1999, Heiligenhaus and Steuhl 1999, Hingorani et al. 1999, Braun 2007).

Over the last few years, in both human and veterinary ophthalmology, a silicone-matrix implant containing cyclosporine A has been used in clinical research studies (Davis et al. 2004, Kim et al. 2005, Gilger et al. 2006, Lee et al. 2007, Boehringer et al. 2008). Those cyclosporine A drug delivery devices have shown to be effective in veterinary ophthalmology in the treatment of two immune-mediated ocular diseases: keratoconjunctivitis sicca in the dog and equine recurring uveitis (Acton et al. 2006, Gilger et al. 2010). A clinical study has been designed at the Tierklinik Hochmoor to examine the safety and efficacy of a local cyclosporine A drug delivery device for the treatment of immune-mediated keratitis with the potential of inducing a therapeutic paradigm shift.

\section{Materials and methods}

\section{Criteria for selection of cases/Test group}

In the time between January 2004 and May 2011, we treated 2,965 ophthalmologic patients at the Tierklinik Hochmoor. Of these, 444 (16.2\%) patients were diagnosed with corneal diseases. Out of this group of horses with corneal diseases, 155 (34.9\%) were treated for immune-mediated keratitis. In summary, $6.2 \%$ of all ophthalmologic patients examined during this time suffered from IMMK. The study at hand refers to 15 patients suffering from mature immunemediated recurring keratitis with vascularization. Four of these horses had superficial keratitis. The remaining 11 horses were diagnosed with midstromal keratitis. Of these 15 patients, six horses were older than ten years (11-19 years) and nine horses were younger than ten years (5-9 years); the mean age was 9.6 years. The test group consisted of five mares and ten geldings. Of the remaining 140 patients treated at the Tierklinik Hochmoor for IMMK during the same time, 64 patients served as a control group respectively as a comparison to the test group since the course of their disea-

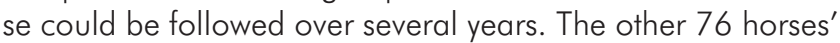
clinical course could not be adequately followed and they were thus not included in the control group. All horses were subject to a complete ophthalmological examination by the same clinician.

In the acute phase, both the patients of the test group and of the control group showed a recurring keratitis with moderate irritation, some superficial blood vessels and a perivascular, epithelial and subepithelial corneal edema at the laterodorsal aspect. The insidious keratitis characteristically occurred unilateral and usually once or twice, sometimes up to three times a year. During the quiet phases of the disease, the cornea appeared without irritation or with a few epithelial pig- 
ment residues. In the horses chosen as test group for this stu$d y$, the chronic keratitis recurred with increasing frequency within weeks to months despite glucocorticoid treatment. All horses were sport horses that were no longer able to compete due to the corneal disease and the associated glucocorticoid treatment. All owners agreed to the intended surgical procedure.

Implant

The implant used in this study was obtained through Professor Brian Gilger at the North Carolina State University College of Veterinary Medicine. It has been tested and used for the

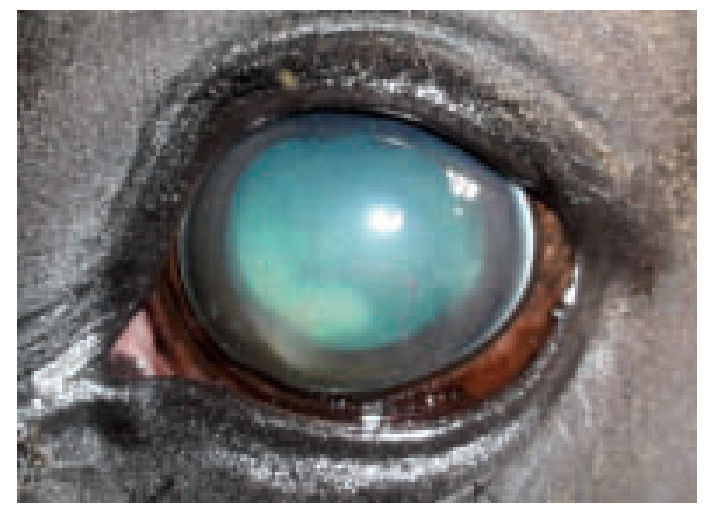

Fig. 3 Left eye of a 6 year-old warmblood gelding, same horse as in Fig. 2. Situation after intensive treatment with a glucocorticoid eye ointment $(0.3 \mathrm{mg} / \mathrm{g}$ dexamethasone and $5.0 \mathrm{mg} / \mathrm{g}$ gentamicin four times daily). The corneal edema is markedly reduced but there is still vascularization present.

Linkes Auge eines biährigen Warmblutwallachs, dasselbe Pferd wie in Bild 2. Situation nach intensiver Behandlung mit Glukokortikoid-haltiger Augensalbe 10,3 mg/g Dexamethason und 0,5mg/g Gentamicin viermal täglich). Das Hornhautödem ist deutlich reduziert, es sind jedoch noch Gefäße zu erkennen.

treatment of equine recurrent uveitis and there have been no detectable toxic side effects locally or systemically. The implant was constructed as previously described: a matrix made of polyvinyl alcohol polymer was loaded with a $10 \%$ cyclosporine A powder pellet. The implant was approximately $2 \mathrm{~mm}$ thick and $6 \mathrm{~mm}$ in diameter. The cyclosporine A delivery device is constructed in such a way that it slowly releases the drug over time. Previous studies have shown that the cyclosporine $A$ is distributed evenly throughout a number of ocular tissues in therapeutic concentrations (Gilger et al. 2006, Gilger et al. 2010).

\section{Procedures and surgical technique}

Prior to the implantation of the cyclosporine A drug delivery device, the horses were treated subconjunctivally and/or topically with dexamethasone (2mg dexamethasone per subconjunctival injection once weekly resp. eye ointment with 0.3 $\mathrm{mg} / \mathrm{g}$ dexamethasone and $5.0 \mathrm{mg} / \mathrm{g}$ gentamicin four times daily) and systemically with NSAIDs $(1.1 \mathrm{mg} / \mathrm{kg}$ flunixin meglumine once daily) until all signs of corneal vascularization ceased in the affected eye (Fig. 3). Cases unresponsive to glucocorticoid treatment, which is reflected by continued vascularization at the episcleral periphery, were treated with a diode laser (Photolase ${ }^{\circledR}$ Diode Laser, type GaAlAs specification, 810 nm wavelength, 5 W power output, Gigaa Optronics Technology Co., Ltd., Wuhan, PRC) prior to implantation. Blood ves- sels at the episcleral periphery were selectively irradiated with a continuous beam (1.5 W power output, $810 \mathrm{~nm}$ wavelength, 0.5 seconds) and a cauterization of the vessels was thus accomplished. The laser treatment was conducted on the standing, sedated horse $(0.03 \mathrm{mg} / \mathrm{kg}$ detomidine) under local anesthesia (oxybuprocainhydrochloride eye drops, $1 \mathrm{ml}$ contains $4.0 \mathrm{mg}$ ). In four of the horses of the test group, the cornea was additionally affected by a non-healing ulcer that was surgically treated in a separate procedure under general anesthesia with a conjunctival pedicle flap prior to implantation. The cyclosporine A drug delivery device was only implanted subsclerally if there were no residual signs of inflammation.

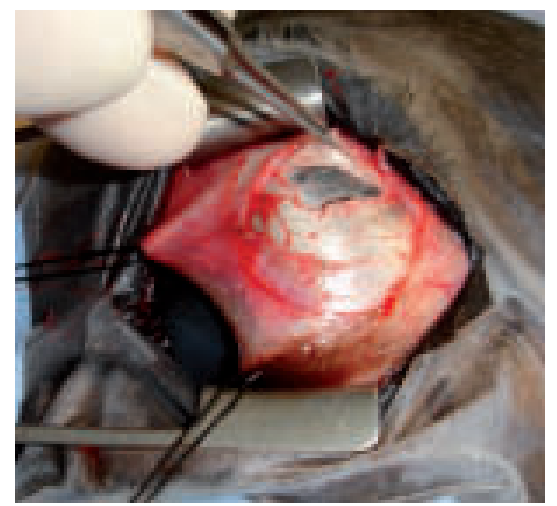

Fig. 4 Intraoperative situation prior to placement of the cyclosporine A implant. Preparation of an L-shaped scleral flap and lamellar dissection from the underlying tissue.

Intraoperative Situation vor dem Einsetzen des Cyclosporin AImplantats. Ein L-förmiger Sklerallappen wurde vom unterliegenden Gewebe abgehoben.

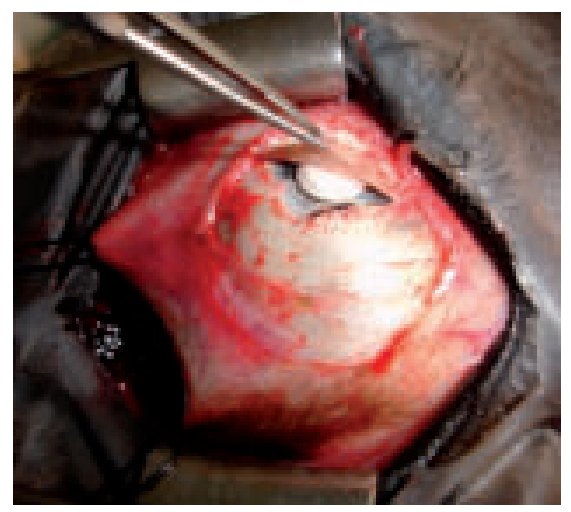

Fig. 5 Intraoperative situation; placement of the cyclosporine A implant underneath the L-shaped scleral flap.

Intraoperative Situation; Einsetzen des Cyclosporin A-Implantats unter den L-förmigen Sklerallappen.

The horses of the test group were then placed under general anesthesia in lateral recumbency with the affected eye on the top side. The cyclosporine A drug delivery devices were implanted between sclera and chorioidea (Fig. 4-6) with a minimally-invasive technique described by Gilger et al. (2010). There were no complications during surgery or in the post-surgical period.

The horses of the control group received the same treatment as the horses of the test group except for the implantation of the cyclosporine A delivery device. Twelve horses of the control group had an accompanying corneal ulcer that in 5 refractory cases needed surgical treatment with a pedicle 
flap; some had to be treated in this way repeatedly. The other cases could either be managed medically or the owners did not agree to a surgical treatment. The efficacy of the treatment with cyclosporine A implants was deduced directly by follow-up examinations, analysis of patient records and photo-documentation and indirectly by questioning the referring veterinarians and owners.

\section{Results}

The objective assessment showed that there was an improvement in $67 \%$ of patients in the test group (Fig. 7). Five patients had no relapse 50-53 months after implantation, four patients had no relapse 40-49 months after implantation, and two horses had no relapse 14-15 months after implantation; these patients were all successfully competing in sport events again. Four horses (33\%) exhibited signs of recurrence between 12 and 20 months after implantation and thus regularly needed treatment with glucocorticoid eye ointments (Table 1). In each case of recurrence the type of IMMK correlated with the type encountered previous to surgery.

Signs of adverse side effects after the implantation of the cyclosporine A drug delivery devices have not been observed

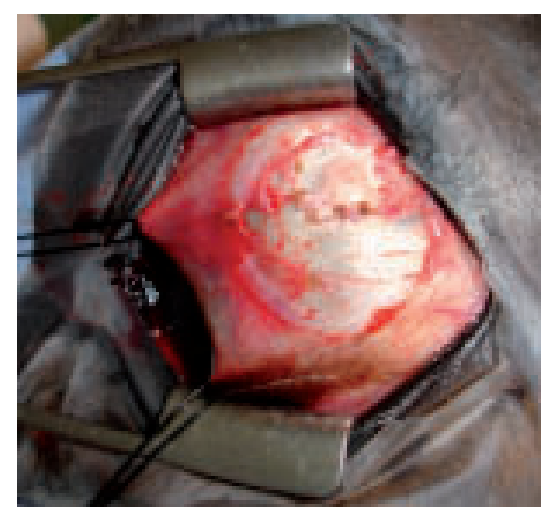

Fig. 6 Intraoperative situation; closure of the L-shaped scleral flap with simple interrupted sutures (5-0 polyglactin 910 absorbable suture material, Vicryl ${ }^{\circledR}$, Ethicon Products, Norderstedt, Germany). Intraoperative Situation; Verschluss des L-förmigen Sklerallappens mit Einzelheften (5-0 Polyglactin 910 absorbierbares Nahtmaterial, Vicry ${ }^{\circledR}$, Ethicon Products, Norderstedt, Deutschland)

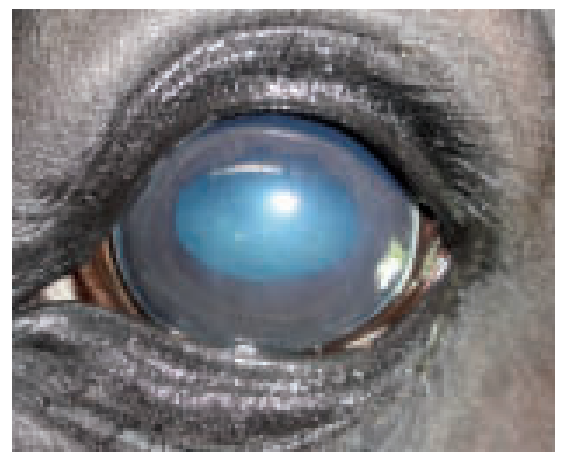

Fig. 7 Left eye of a 6 year-old warmblood gelding, same horse as in Fig. 2 and 3. Situation 4 months after subscleral placement of a cyclosporine A implant. In some cases, as seen here, a slight corneal opacity remained.

Linkes Auge eines 6jährigen Warmblutwallachs, dasselbe Pferd wie in Bild 2 und 3. Situation 6 Monate nach Einsetzen des Cyclosporin AImplantats. In manchen Fällen verblieb eine leichte Hornhauttrübung, wie hier zu erkennen ist. so far. Side effects that have been reported after the topical treatment with glucocorticoids (glaucoma, cataract, secondary infections, dry eye) were not seen either.

In the horses of the control group, the IMMK kept recurring at an average of one to three times a year. At each occasion, the type of IMMK corresponded to the type diagnosed before. Some of the horses of the control group that were surgically treated with pedicle flaps experienced a recurrence of the IMMK in a different part of the cornea from the treated area (Fig. 8).
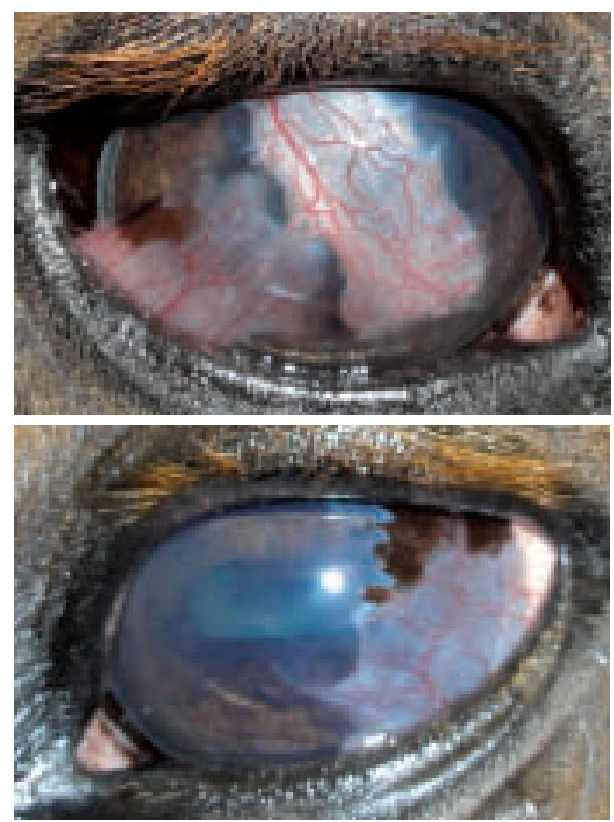

Fig. 8 Right (above) and left (below) eye of a 12 year-old warmblood gelding from the control group. This horse suffered from midstromal keratitis, complicated by non-healing corneal ulcers in both eyes that recurred despite intensive treatment. The horse repeatedly needed conjunctival pedicle flaps to treat the ulcers.

Rechtes (oben) und linkes (unten) Auge eines 12jährigen Warmblutwallachs aus der Kontrollgruppe. Dieses Pferd litt an einer midstromalen Keratitis, die durch nichtheilende Hornhautulzera auf beiden Augen verkompliziert wurde. Die Keratitis rezidivierte trotz intensiver Behandlung. Dieses Pferd wurde wiederholt mit konjunktivalen Stiellappenplastiken versorgt um die Hornhautulzera zu behandeln.

\section{Discussion}

This study describes the clinical experience and long-term outcome after suprachoroidal implantation of a cyclosporine A drug delivery device in horses with IMMK. To date, the longterm benefits of this therapy have lasted 50-53 months; it can thus be deduced that the cyclosporine $A$ treatment by means of a subscleral drug delivery device is an effective method to treat the recurrence of IMMK. The cyclosporine A drug delivery device has been tested and used for the treatment of equine recurrent uveitis; studies regarding this treatment have shown an efficacy of up to 48 months (Gilger et al. 2010). It remains to be seen how long the immunosuppressant effect lasts in cases with IMMK. Also, the test group in this study is relatively small with 15 horses and further studies are required to confirm or refute this study's results. In many cases, the owners of the control group's patients did not want a surgical treatment of their horses and opted for a medical treatment 


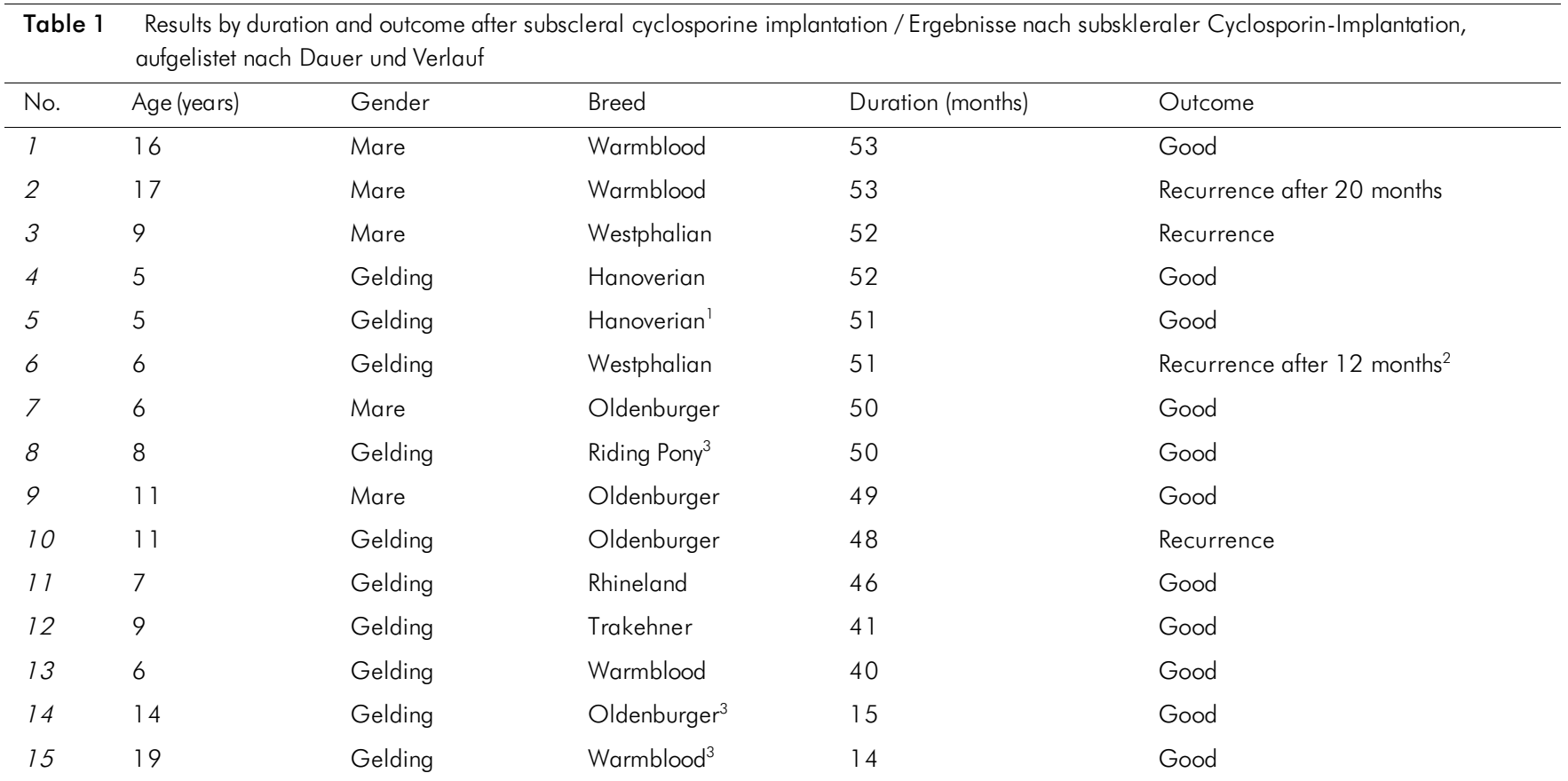

${ }^{1}$ Fungal infection and corneal ulcer; pedicle flap, ${ }^{2}$ Horse sold to Russia; no further information available, ${ }^{3}$ Corneal ulcer; pedicle flap

only, so that the test group could not be expanded. Four of the 15 test horses of this study showed signs of recurrence after implantation. This insufficient result could, among other reasons, be due to incorrect implantation or implantation during an active phase of IMMK that was not detected.

Also, four of the test horses in this study had corneal ulcers prior to implantation as a complication to the IMMK. Typically, IMMK is not accompanied by corneal ulceration. All four horses had been subjected to long-term glucocorticoid treatment by the referring veterinarians prior to presentation. The prolonged exposure to glucocorticoids could be responsible for the development of the corneal ulcers in these cases.

There is some debate over whether or not cyclosporine A applied topically through drops or ointments generates therapeutic concentrations in the cornea and anterior chamber. It appears that the level of immunosuppression is not always sufficient (BenEzra and Maftzir 1990, Minguez et al. 1992, Gratzek et al. 1995, Althaus et al. 1996, Tran 1997, Heiligenhaus and Steuhl 1999, Zheng et al. 2002). Several in vitro and in vivo studies have been performed to evaluate the distribution of cyclosporine $A$ in the eye after suprachoroidal implantation of a cyclosporine A drug delivery device. Those studies have shown that after implantation cyclosporine $A$ can be found in therapeutic concentrations in various ocular tissues (Gilger et al. 2006, Gilger et al. 2010). One report by Gilger et al.(2006) found no measurable concentration of cyclosporine $A$ in the cornea after suprachoroidal implantation of the drug delivery device. Yet, the results of the study at hand indicate a certain effect against IMMK. This could be based upon the fact that IMMK is thought to be not solely a disease of the cornea but rather a type of anterior uveitis (Parma et al. 1985, Parma et al. 1987, Holland et al. 1993, Lucchesi and Parma 1999, Lucchesi et al. 2002, Wada et al. 2003). It might also explain why topically applied eye ointment does not reliably control IMMK as it does not diffuse into the deeper layers but instead only affects the superficial tissues (Bleik and Tabbara 1991, Sec- chi et al 1997). Thus, the positive effect on eyes affected with IMMK is probably not only due to the concentrations reached within corneal tissue. A therapeutic concentration of cyclosporine $A$ in the anterior uvea and the immunosuppressive effect caused by it is more likely to be responsible for the results yielded by this study. It remains to be seen whether or not cyclosporine A implants affect other, nonimmune mediated types of keratitis as there was no measurable concentration in the cornea.

Patients needing long-term treatment and patients needing glucocorticoid treatment could benefit greatly from the subscleral cyclosporine A implant. Glucocorticoids are potent agents for the suppression of a dysfunctional immune response but they can have serious adverse side effects. Topically applied, they can cause glaucoma, cataract and dry eye. Also, they can promote secondary bacterial and fungal infections. If used systemically, glucocorticoids can, among others, cause gastrointestinal and metabolic problems. Both methods of application have to be conducted at least once daily which can make owner/patient compliance a challenge. Ideally, no further medication is needed after the implantation of the cyclosporine A drug delivery device as it produces a longterm therapeutic cyclosporine A concentration in the eye, making it superior to other forms of treatment. Additionally, the concentrations obtained through the use of a drug delivery device are approximately one hundred times higher than those achieved through topical application of cyclosporine $A$ drops or ointments (Kim et al. 2005, Lee et al. 2007, Boehringer et al. 2009).

Cyclosporine implants and their potential ability to reduce graft rejection after corneal transplants have recently been investigated in international multicentered human ophthalmologic trials. The results of these studies are unfortunately not available yet but results from animal studies promise a novel, pivotal treatment modality against graft rejection and graft loss (Kim et al. 2005, Lee et al. 2007, Boehringer et al. 2008, Boehringer et al. 2009). 
The therapy can be used in sport horses suffering from frequently recurring IMMK that could not be competed otherwise. The plasma concentrations of topically applied cyclosporine $A$, and this is also true for the cyclosporine $A$ implants, are so low that - as of yet - they can either not be detected or only through the use of complex measuring methods (Althaus et al. 1996, Gilger et al. 2006). Yet, the local concentrations in the eye are high. This local accumulation not only dramatically reduces systemic toxicity: a systemic effect that can be rated as positive or negative doping is thus improbable. Nevertheless, it remains a matter of discussion whether or not such a permanent treatment can be considered as a form of doping. The horse's condition pre-treatment would not allow participation at a competition, whereas after treatment the horse can compete with no physical limitation such as impaired vision or painful inflammation.

In 6.5 years, $6.2 \%$ of all horses treated at the Tierklinik Hochmoor for ophthalmologic problems were diagnosed with IMMK. Studies performed in North America stated lower numbers of IMMK patients which raises the question whether IMMK possibly occurs more frequently in Europe than in North America (Gilger et al. 2005). Multi-centered studies aimed at this problem could elucidate whether the detected difference really depends on geography.

\section{Conflict of interest}

The authors declare no conflict of interest.

\section{Acknowledgements}

We would very much like to thank Professor Brian Gilger and his team at NCSU for their help and assistance with the acquisition of the cyclosporine $A$ implants and the review of this publication. We would also like to thank Dr. Lieke Dikker for her help with the preparation of this publication.

\section{References}

Abadia F., Videcoq C., Alamartine E., Berthoux F. and Mariat C. (2009) Differential effect of cyclosporine and mycophenolic acid on the human regulatory $\mathrm{T}$ cells and $\mathrm{TH}-17$ cells balance. Transplant. Proc. 41, 3367-3370
Acheampong A. A., Shackleton M., Tang-Liu D. D., Ding S., Stern M. E. and Decker R. (1999) Distribution of CSA on ocular tissues after topical administration to albino rabbits and beagle dogs. Curr. Eye Res. 18, $91-103$

Acton A. E., Beale A. B., Gilger B. C. and Stoskopf M. K. (2006) Sustained release cyclosporine therapy for bilateral keratoconjunctivitis sicca in a red wolf (Canis Rufus). J. Zoo Wildlife Med. 37, 562-564.

Althaus C., Dagres E., Reinhard T., Christians U. and Sundmacher R. (1996) Cyclosporine and its metabolites in the anterior chamber after topical and systemic application as determined with high-performance liquid chromatography-electrospray mass spectrometry. Der Ophthalmologe 5, 189-194

BenEzra D. and Maftzir G. (1990) Ocular penetration of Cyclosporine A: the human eye. Brit. J. Ophthalmol. 74, 350-352

BenEzra D., Peter J., Brodsky M. and Cohen E. (1986) Cyclosporine Eyedrops for the Treatment of Severe Vernal Keratoconjunctivitis. Am. J. Ophthalmol. 101, 278-282

Bleik J. and Tabbara K. (1991) Topical Cyclosporine in Vernal Keratoconjunctivitis. Ophthalmol. 98, 1679-1684

Boehringer D., Goos D., Birnbaum F. und Reinhard T. (2008) Episklerale Cyclosporin-A Implantate zur Prävention von Abstossungsreaktionen nach Keratoplastik. 106. Kongr. Deutschen Ophthalmol. Ges. Berlin, Germany

Boehringer D., Schwartzkopf J., Huber K., Joussen A., Seitz B., Lohmann C., Messmer E., Cursiefen C., Kruse F., Geerling G., Meller D., Noelle B. and Reinhard T. (2009) Prävention von Abstossungsreaktionen nach Keratoplastik mittels episkleralem Cyclosporin A-freisetzendem Medikamententräger: die Lucida Studien. 107. Kongr. Deutschen Ophthalmol. Ges. Leipzig, Germany

Borel J. F., Feurer C., Gubler H. U. and Staehelin H. (1976) Biological effects of cyclosporine A: a new antilymphocytic agent. Ag. Act. 6, 468-475

Braun M. (2007) Effektivität der lokalen Cyclosporin A Therapie bei entzündlichen Erkrankungen von Hornhaut und Bindehaut. Dissertation, Heinrich-Heine-Universität Düsseldorf

Brooks D. E., Millichamp N. J., Peterson M. G., Laratta L. J., Morgan R. V. and Dziezyc J. (1990) Nonulcerative keratouveitis in five horses. J. Am. Vet. Med. Assoc. 196, 1985-1991

Cao S., Cox K.L., Berquist W., Hayashi M., Concepcion W., Hammes G. B., Ojogho O. K., So S. K., Frerker M., Castillo R. O., Monge H. and Esquivel C. O. (1999) Long-term outcomes in pediatric liver recipients: comparison between Cyclosporine A and tacrolimus. Ped. Transplant. 3, 22-26

Clode A. B. and Matthews A. (2011) Diseases and surgery of the cornea. In: Equine Ophthalmology (ed. Gilger, B.C.) 2nd ed. Elsevier, Philadelphia, PA, 181-266.

Davis J., Gilger B. C. and Robinson M. (2004) Novel approaches to ocular drug delivery. Curr. Op. Molec. Ther. 6, 195-205 
Douglas L. C., Yi N. Y., Davis J. L., Salmon J. H. and Gilger B. C. (2008) Ocular toxicity and distribution of subconjunctival and intravitreal rapamycin in horses. J. Vet. Pharmacol. Therap. 31, 51 1-516

Dua H. S., Jindal V. K., Gomes J. A., Amoaku W. A., Donoso L. A., Laibson P. R. and Mahlberg K. (1996) The effect of topical cyclosporine on conjunctiva-associated lymphoid tissue (CALT). Eye 10, 433-438

Freisen H. A. (1993) Cyclosporin - ein never Weg bei rassespezifischen Keratitiden des Hundes. Prakt. Tierarzt 2, 108-1 10

Gao J., Schwalb T. A., Addeo J. V., Ghosn C. R. and Stern M. E. (1998) The role of apoptosis in the pathogenesis of canine keratoconjunctivitis sicca: the effect of topical CSA therapy. Cornea $17,654-663$

Gilger B. C., Miller Michau T. and Salmon J. H. (2005) Immunemediated keratitis in horses: 19 cases (1998-2004). Vet. Ophthal. 8, 233-239

Gilger B. C., Salmon J. H., Wilkie D. A., Cruysberg L. P. J., Kim J., Hayat M., Kim H., Kim S., Yuan P., Lee S. S., Harrington S. M., Murray P. R., Edelhauser H. F., Csaky K. G. and Robinson M. R. (2006) A novel bioerodible deep scleral lamellar cyclosporine implant for uveitis. Invest. Ophthalmol. Vis. Sc. 47, 2596-2605

Gilger B. C., Wilkie D. A., Clode A. B., McMullen R. J. Jr., Utter M. E., Komaromy A. M., Brooks D. E. and Salmon J. H. (2010) Longterm outcome after implantation of suprachoroidal cyclosporine drug delivery device in horses with recurrent uveitis. Vet. Ophthalmol. 13, 294-300

Gratzek A. T., Kaswan R. L., Martin C. L., Champagne E. S. and White S. L. (1995) Ophthalmic cyclosporine in equine keratitis and keratouveitis: 11 cases. Equine Vet. J. 27, 327-333

Heiligenhaus A. and Steuhl K. (1999) Treatment of HSV-1 stromal keratitis with topical cyclosporine A: a pilot study. Graefe's Arch. Clin. Exp. Ophthalmol. 237, 435-438

Hingorani M., Calder V. L., Buckley R. J. and Lightman S. (1999) The immunomodulatory effect of topical CSA in atopic keratoconjunctivitis. Invest. Ophthalmol. Vis. Sc. 40, 392-399

Holland E. J., Olsen T. W., Ketcham J. M., Florine C., Krachmer J. H., Purcell J. J., Lam S., Tessler H. H. and Sugar J. (1993) Topical Cyclosporine $A$ in the treatment of anterior segment inflammatory disease. Cornea 12, 413-419

Kawai M., Kitade H., Mathieu C., Waer M. and Pirenne J. (2005) Inhibitory and stimulatory effects of cyclosporine $A$ on the development of regulatory T cells in vivo. Transplant. 79, 1073-1077

Kay J. (1989) Inhibitory effects of cyclosporine A on lymphocyte activation. In: Cyclosporine: Mode of Action and Clinical Application (ed. Thomson, A.) Kluwer Academic Publishers, Dordrecht, 1-23.

Kellner S. J. (1990) Hornhauterkrankungen beim Pferd. Pferdeheilkunde 6, 163-168

Kim H., Csaky K. G., Gilger B. C., Dunn J. P., Lee S. S., Tremblay M., de Monasterio F., Tansey G., Yuan P., Bungay P. M., Lutz R. J. and Robinson M. R. (2005) Preclinical evaluation of a novel episcleral cyclosporine implant for ocular graft-versus-host disease. Invest. Ophthalmol. Vis. Sc. 46, 655-662

Kopf H., de la Rosa G. M., Howard O. M. and Chen X. (2007) Rapamycin inhibits differentiation of Th17 cells and promotes generation of FoxP3 + T regulatory cells. Int. Immunopharmacol. 7, 1819-1824

Lee S. S., Kim H., Wang N. S., Bungay P. M., Gilger B. C., Yuan P., Kim J., Csaky K. G. and Robinson M. R. (2007) A pharmacokinetic and safety evaluation of an episcleral cyclosporine implant for potential use in high-risk keratoplasty rejection. Invest. Ophthalmol. Vis. Sc. 48, 2023-2029

Liu X., Yang P., Lin X., Ren X., Zhou H., Huang X., Chi W., Kiilstra A. and Chen L. (2009) Inhibitory effect of Cyclosporine A and corticosteroids on the production of IFN-gamma and IL-17 by T cells in VogtKoyanagi-Harada syndrome. Clin. Immunol. 131, 333-342

Lucchesi P. M. and Parma A. E. (1999) A DNA fragment of Leptospira interrogans encodes a protein which shares epitopes with equine cornea. Vet. Immunol. Immunopathol. 71, 173-179

Lucchesi P. M., Parma A. E. and Arroyo G. H. (2002) Serovar distribution of a DNA sequence involved in the antigenic relationship between Leptospira and equine cornea. BMC Microbiol. 2, 3
Mabon P. J., Weaver L. C. and Dekaban G. A. (1999) Cyclosporine A reduces the inflammatory response to a multi-mutant herpes simplex virus type-1 leading to improved transgene expression in sympathic preganglionic neurons in hamsters. J. Neurovirol. 5, 268-279

Maske R., Hill J. C. and Horak S. (1994) Mixed lymphocyte culture responses in rabbits undergoing corneal grafting and topical cyclosporine treatment. Cornea 13, 324-330

Matthews A. G. (2000) Nonulcerative keratopathies in the horse. Equine Vet. Ed. 12, 271-278

Matthews A. and Gilger B. C. (2009) Equine immune mediated keratopathies. Vet. Ophthalmol. 12, 10-16

Matthews A. and Gilger B. C. (2010) Equine immune mediated keratopathies. Equine Vet. J. 37, 62-68

Minguez E., Tiestos M. T., Cristobal J. A., Castillo J., Dapena M. P. and Palomar A. (1992) Intraocular absorption of cyclosporine A eyedrops. J. Fr. Ophthalmol. 15, 263-267

Parma A. E., Fernandez A. S., Santisteban C. G., Bowden R. A. and Cerone S. I. (1987) Tears and aqueous humor from horses inoculated with Leptospira contain antibodies which bind to cornea. Vet. Immunol. Immunopathol. 14, 181-185

Parma A. E., Santisteban C. G., Villalba J. S. and Bowden R. A. (1985) Experimental demonstration of an antigenic relationship between Leptospira and equine cornea. Vet. Immunol. Immunopathol. 10, 215-224.

Reinhard T., Sundmacher R. and Heering P. (1996) Systemic Cyclosporine A in highrisk keratoplasty. Graefe's Arch. Clin. Exp. Ophthalmol. 234, 115-121

Ruhlmann A. and Nordheim A. (1997) Effects of the immunosuppressive drugs CSA and Fk 506 on intracellular signaling and gene regulation. Immunobiology 198, 192-206

Secchi A., Tognon S. and Leonardi A. (1997) Topical Use of Cyclosporine in the Treatment of Vernal Keratoconjunctivitis. Am. J. Ophthalmol. 110,641-645

Sigal N. H. and Dumont F. J. (1992) Cyclosporine A, FK-506, and rapamycin: pharmacologic probes of lymphocyte signal transduction. Ann. Rev. Immuno. 10, 519-560.

Soter N. A., Fleischer A. B. Jr, Webster G. F., Monroe E. and Lawrence I. (2001) Tacrolimus ointment for the treatment of atopic dermatitis in adult patients: part II, safety. J. Am. Acad. Dermatol. 44, 39

Toth J., Hollerrieder J.und Sotonyi P. (2010) Augenheilkunde beim Pferd. Schattauer Verlag, Stuttgart

Tran U. (1997) Human corneal levels of topically applied immunosuppressants. Invest. Ophthalmol. Vis. Sc. 38, 858

Wada S., Yoshinari M., Katayama Y., Anzai T., Wada R. and Akuzawa M. (2003) Nonulcerative keratouveitis as a manifestation of Leptospiral infection in a horse. Vet. Ophthalmol. 6, 191-195

Williams D. L. (1997) A comparative approach to topical cyclosporine therapy. Eye 11, 453-464

Zhang E., Schulte F., Bulfone-Paus S. and Hoffmann F. (2000) The effect of corticosteroid and cyclosporine A on murine corneal allograft rejection. Graefe's Arch. Clin. Exp. Ophthalmol. 238, 525530

Zhang C., Zhang J., Yang B. and Wu C. (2008) Cyclosporine A inhibits the production of IL-17 by memory Th 17 cells from healthy individuals and patients with rheumatoid arthritis. Cytokine 42, 345-352

Zheng J., Zhou L., Tan D. and Lam K. W. (2002) Distribution of Cyclosporine A in the Cornea after Topical or Oral Administration. J. Oc. Pharmacol. Therap. 18, 83-88

Prof. Dr. Dr. J. Toth

Tierärztliche Klinik Domäne Karthaus

Weddern $16 \mathrm{c}$

48249 Dülmen

prof.toth@tierklinik-karthaus.de 